\title{
Bean Rust Control under Field Conditions with Systemic and Contact Fungicides ${ }^{1}$
}

\author{
Pedro L. Meléndez, Rocio Rodriguez, and Linda Wessel-Beaver ${ }^{2}$
}

\begin{abstract}
Bean rust (Uromyces appendiculatus) was generally controlled with both contact and systemic fungicides on three cultivars (Blanca del Pais, Bountiful and Naranjito) tested at two locations in Puerto Rico. However, effectiveness varied with rate, cultivar, location and disease level. On cultivars in Lajas, contact fungicides chlorothalonil and mancozeb were more effective in reducing disease symptoms and in increasing yields than the systemic fungicides oxycarboxin and triforine. There were fewer differences between fungicides in Isabela, where disease incidence was lower, but contact fungicides again were generally more effective. Mancozeb was the most effective fungicide, reducing disease symptoms and increasing yields. Certain fungicides combined with genetic resistance should be effective in increasing bean yields.
\end{abstract}

\section{INTRODUCTION}

Dry beans (Phaseolus vulgaris L.) are a major source of protein for millions of people in the humid tropics. The expected increase in human population is likely to bring about further dependence on this legume. To provide reasonable assurance that an adequate supply of this basic legume will be available to satisfy protein needs in the future, agronomists should study practices that will increase production. Control of diseases is an essential component of any set of technological practices geared to improve production levels.

Rust, caused by the fungus Uromyces appendiculatus, is one of the most severe bean foliage diseases. The earliest symptoms of the disease are often overlooked because they appear as small chlorotic spots on the leaves. As they grow and invasion proceeds, the chlorotic spots become larger and rust-colored pustules occur on both leaf surfaces associated with disease areas (fig. 1). Leaves turn yellowish, and when infection is severe, they dry up and fall. Under moderate to severe infections, when much of the leaf surface is destroyed, yields are reduced.

The objective of this research was to test the effectiveness of systemic and contact fungicides in controlling bean rust under field conditions in Puerto Rico on resistant and susceptible bean cultivars.

\footnotetext{
'Manuscript submitted to Editorial Board January 31, 1985.

${ }^{2}$ Associate Dean of the Faculty of Agriculture and Phytopathologist; Assistant Phytopathologist, Department of Crop Protection; and Associate Plant Breeder, Department of Agronomy and Soils, College of Agricultural Sciences, University of Puerto Rico, Mayagüez, Puerto Rico 00708.
} 


\section{MATERIALS AND METHODS}

Four experiments were established to test the effectiveness of oxycarboxin, triforine, mancozeb, chlorothalonil, and benomyl in controlling bean rust. These trials were established in August 1974 and March 1975 at the Isabela Research and Development Center, and in February 1976 at both the Isabela and Lajas Research and Development Centers of the University of Puerto Rico, covering an area of 0.12 ha. Rust susceptible

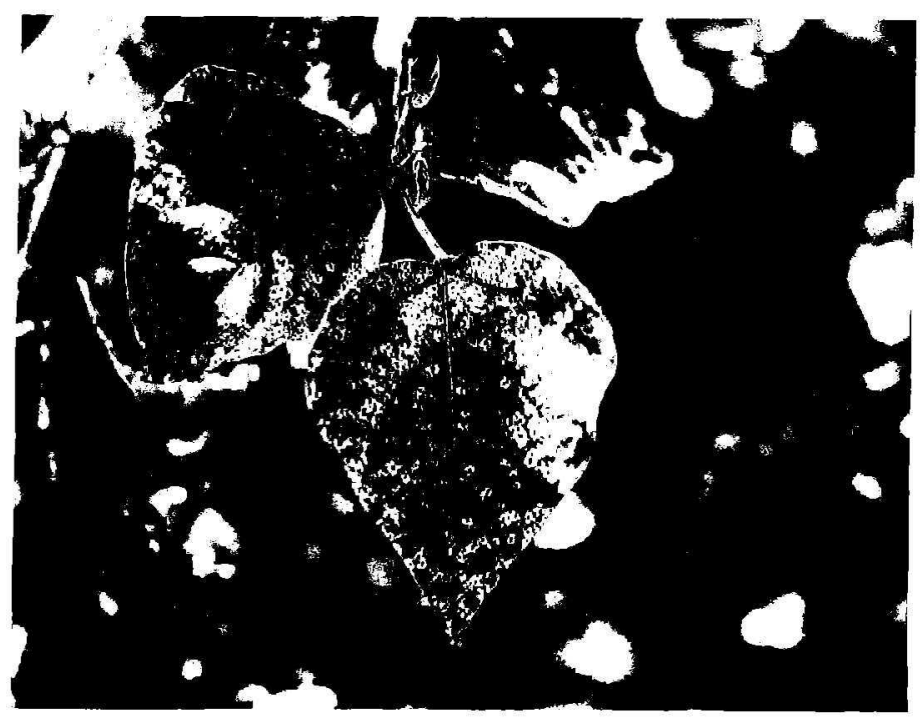

Fig. 1.-Symptoms of rust disease characterized by rust-colored pustules scattered throughout the leaf surface.

bean cv. Blanca del País (fig. 2) and Bountiful, and rust resistant cv. Naranjito were used as test plants. A partially-balanced incomplete-block design with five replicates was used. Each trial consisted of four fungicides at two dosages applied to two bean cultivars, plus controls, for a total of 18 treatments. Rates of oxycarboxin, mancozeb, and chlorothalonil were 1.12 and $2.24 \mathrm{~kg} / \mathrm{ha}$; rates of benomyl and triforine were 0.28 and $0.60 \mathrm{~kg} / \mathrm{ha}$, and 0.60 and $1.12 \mathrm{~kg} / \mathrm{ha}$, respectively. Treatments were applied to the foliage with a knapsack sprayer. Except for benomyl, which was applied bi-weekly, all other fungicides were applied on a weekly 
basis. At planting time, a 10-10-8 fertilizer was applied at a rate of 2.24 $\mathrm{kg} / \mathrm{plot}$ plus Dacthal $75 \mathrm{~W}$ at a rate of $3.36 \mathrm{~kg} / \mathrm{ha}$. After emergence, weeds were controlled by handweeding and insect damage was checked by weekly applications of Diazinon AG-500. Plants of the middle row of each plot in the 1976 trials were artificially inoculated by rubbing the foliage with uredospore-loaded bean leaves obtained from other diseased bean plots at Lajas.

To compare treatments, disease indices and yield data were recorded.

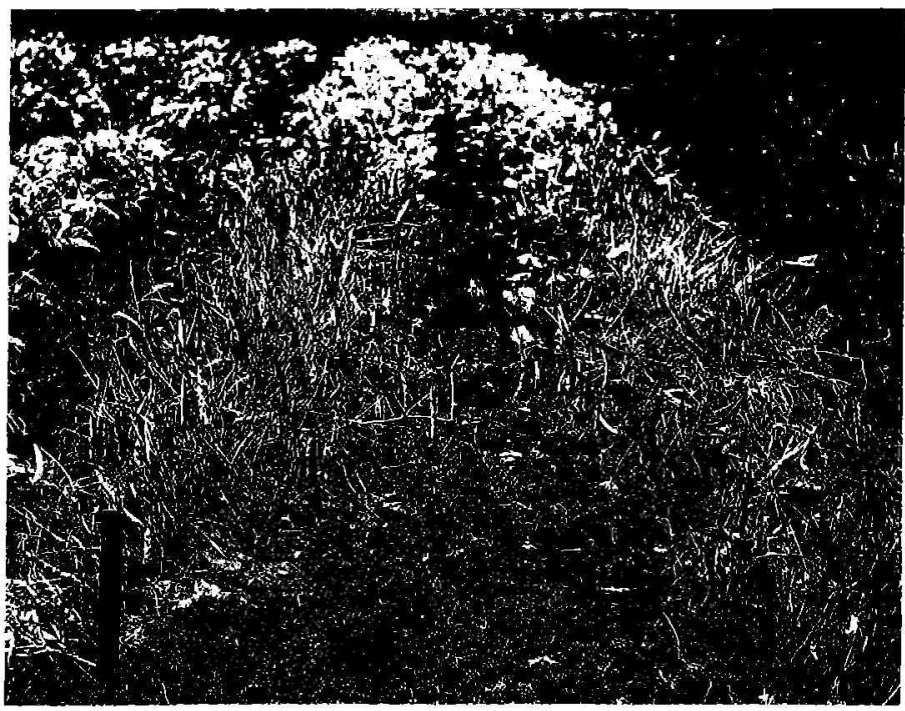

FIG. 2,-Defoliation on bean cv. Blanca del Pais due to rust infection in non-sprayed plot.

Disease indices were calculated using the formula of Sherwood and Hagedorn (5). Scoring was done based on defoliation in 1974 and 1975, and for both defoliation and pustule intensity in 1976. The disease class score used in the formula went from 0 for no disease or defoliation, to 5 for $80-100 \%$ disease or defoliation.

Data was subjected to analysis of variance. Differences were considered significant if $P \leq 0.05$. A one-tailed Dunnet's test was used to compare treatments with their corresponding controls. Other comparisons were made with $t$-tests. All tests were done with the adjusted treatment means, but the original means appear in the tables. 


\section{RESULTS AND DISCUSSION}

Disease index data from the August 1974 trial (table 1) indicated that oxycarboxin protected cv. Bountiful, but failed to protect cv. Blanca del País from attack by $U$. appendiculatus. Triforine and mancozeb effectively protected both cultivars against the invasion of this pathogen, but benomyl did not control rust. Yields from mancozeb treated plots were significantly different from check plots for both cultivars. Mancozeb was the most effective fungicide in this trial. Overall yields were low because of adverse environmental conditions at harvest.

In the second experiment, rust occurred early in the season (April),

TABLE 1.-Yield and disease index of bean cus. Blanca del Pais and Bountiful treated with fungicides to control lenf rust, August 1974, Isabela, P.R.

\begin{tabular}{|c|c|c|c|c|c|}
\hline \multirow{3}{*}{ Treatment } & \multirow{3}{*}{ Rate } & \multicolumn{4}{|c|}{ Cultivar } \\
\hline & & \multicolumn{2}{|c|}{ Blanca del Pais } & \multicolumn{2}{|c|}{ Bountiful } \\
\hline & & $\begin{array}{l}\text { Disease } \\
\text { Index }\end{array}$ & Yield $^{3}$ & $\begin{array}{l}\text { Disesse } \\
\text { Index }\end{array}$ & Yield' \\
\hline & $\mathrm{kg} / \mathrm{ha}$ & & $\mathrm{hg} / \mathrm{ha}$ & & $\mathrm{kg} / \mathrm{ha}$ \\
\hline Oxycarboxin & 1.12 & 62 & 500 & $38^{* 2}$ & 222 \\
\hline Oxycarboxin & 2.24 & 58 & 480 & $42^{*}$ & 240 \\
\hline Triforine & 0.60 & $52^{*}$ & 590 & $36^{*}$ & 253 \\
\hline Triforine & 1.12 & $56^{*}$ & 430 & $42^{*}$ & 206 \\
\hline Mancozeb & 1.12 & $34^{* * 3}$ & $746^{*}$ & $40^{*}$ & $297^{*}$ \\
\hline Mancozeb & 2.24 & $30^{* *}$ & $830^{*}$ & $42^{*}$ & $307^{*}$ \\
\hline Benomyl & 0.28 & 68 & 571 & 46 & 180 \\
\hline Benomyl & 0.60 & 70 & 467 & 50 & 189 \\
\hline Check & & 76 & 492 & 80 & 185 \\
\hline
\end{tabular}

1 Yields in general were low because of adverse environmental conditions at harvest time.

2 Significantly different over the check at $P=0.05$.

${ }^{3}$ Significantly different over the check at $\mathrm{P}=0.01$.

mainly on cv. Bountiful. However, the high disease indices shown in table 2 are partially due to an outbreak of bacterial blight during the heavy rains of May that completely defoliated the plants. Blight occurred late in the season when differences in yields of $\mathrm{cv}$. Bountiful were not likely to be influenced by this disease. Only two chemicals significantly increased yields of cv. Bountiful: oxycarboxin $(2.24 \mathrm{~kg} / \mathrm{ha})$ and chlorothalonil $(1.12 \mathrm{~kg} / \mathrm{ha})$. None of the fungicides evaluated protected $\mathrm{cv}$. Blanca del Pais against rust. However, yields were high for all treatments, suggesting that rust was not a limiting factor.

In 1976 at Isabela, fungicides were effective in reducing pustule intensity and degree of defoliation, and in increasing yields in Blanca del Pais 
(table 3). Mancozeb and chlorothalonil were especially effective in controlling disease symptoms and increasing yields. The lowest dosages of these fungicides were as effective as the high dosages. At Isabela, Naranjito appeared almost free of rust even in the control (nonsprayed) plots.

Because of greater disease incidence, the effectiveness of fungicide application was more evident in 1976 at Lajas (table 4). Nearly all concentrations of fungicide treatments were effective in reducing pustules and defoliation (fig. 3). However, although disease incidence was reduced through the use of fungicides, incidence remained high in susceptible ev. Blanca del Pais. In this cultivar yield levels were significantly increased

TABLE 2.-Yield and disease index of bean cu. Blanca del Pais and Bountiful treated with fungicides to control leaf rust, March 1975, Isabela, P.R.

\begin{tabular}{|c|c|c|c|c|c|}
\hline \multirow{3}{*}{ Treatment } & \multirow{3}{*}{ Rate } & \multicolumn{4}{|c|}{ Cultivar } \\
\hline & & \multicolumn{2}{|c|}{ Blanca del Pais } & \multicolumn{2}{|c|}{ Bountiful } \\
\hline & & $\begin{array}{l}\text { Disease } \\
\text { Index }\end{array}$ & Yield & $\begin{array}{l}\text { Disease }^{t} \\
\text { Index }\end{array}$ & Yield \\
\hline & $k g / h a$ & & $\mathrm{~kg} / \mathrm{ha}$ & & $\mathrm{kg} / \mathrm{ha}$ \\
\hline Oxycarboxin & 1,12 & 58 & 2221 & 100 & 954 \\
\hline Oxycarboxin & 2.24 & 72 & 2153 & 100 & $1268^{1}$ \\
\hline Triforine & 0.60 & 68 & 2262 & 100 & 1166 \\
\hline Triforine & 1.12 & 68 & 1850 & 100 & 1011 \\
\hline Mancozeb & 1.12 & 68 & 2183 & 100 & 1205 \\
\hline Mancozeb & 2.24 & 60 & 2152 & 100 & 1195 \\
\hline Chlorothalonil & 1.12 & 62 & 2047 & 100 & $1369^{*}$ \\
\hline Chlorothalonil & 2.24 & 60 & 2270 & 100 & 1145 \\
\hline Check & & 68 & 2233 & 100 & 801 \\
\hline
\end{tabular}

${ }^{1}$ There were no significant differences among treatments. High disease indices are partly due to an outbreak of bacterial blight which completely defoliated the plants.

${ }^{2}$ Significantly different over the check at $P=0.05$.

with all fungicides except triforine. In cv. Naranjito, high rates of systemic fungicides chlorothalonil and mancozeb improved yields. This suggested that the combination of resistance and fungicide application could improve yield under certain conditions.

Within a location, oxycarboxin and triforine (systemic fungicides), averaged over all rates, did not differ significantly from each other in pustule intensity, defoliation, or yield (tables 3 and 4). As a group, these two fungicides behaved similarly. Although the contact fungicides chlorothalonil and mancozeb also responded similarly to each other in most instances, when they did vary, mancozeb was the more effective of the two fungicides. 
TABLE 3.-Disease index and yield of bean cu. Bonita and Naranjito at Isabela treated with fungicides to control leaf rust, February 1976

\begin{tabular}{|c|c|c|c|c|c|c|c|}
\hline \multirow{4}{*}{ Treatment } & \multirow{4}{*}{ Rate } & \multicolumn{6}{|c|}{ Cultivar } \\
\hline & & \multicolumn{3}{|c|}{ Blanca del Pais } & \multicolumn{3}{|c|}{ Naranjito } \\
\hline & & \multicolumn{2}{|c|}{ Disease index } & \multirow[b]{2}{*}{ Yield } & \multicolumn{2}{|c|}{ Disease index } & \multirow[b]{2}{*}{ Yield } \\
\hline & & $\begin{array}{c}\text { Pustule } \\
\text { intensity }\end{array}$ & $\begin{array}{c}\text { Degree of } \\
\text { defoliation }\end{array}$ & & $\begin{array}{c}\text { Pustule } \\
\text { intensity }\end{array}$ & $\begin{array}{c}\text { Degree of } \\
\text { defoliation }\end{array}$ & \\
\hline & $\mathrm{kg} / \mathrm{ha}$ & & & $\mathrm{kg} / \mathrm{ha}$ & & & $\mathrm{kg} / \mathrm{ha}$ \\
\hline Oxycarboxin & 1.12 & $12^{* * 1}$ & $48^{* *}$ & $2416^{* 2}$ & 4 & 0 & 2080 \\
\hline Oxycarboxin & 2.24 & $4^{* *}$ & $24^{* *}$ & $2424^{*}$ & 4 & 0 & 2170 \\
\hline Triforine & 0.60 & $8^{* *}$ & $44^{* *}$ & $2422^{*}$ & 1 & 0 & 2225 \\
\hline Triforine & 1.12 & $0^{* *}$ & $36^{* *}$ & $2367^{*}$ & $0^{* *}$ & 0 & 2032 \\
\hline Chlorothaloni] & 1.12 & $4^{* *}$ & $28^{* *}$ & $2799^{* *}$ & 4 & 0 & 2343 \\
\hline Chlorothalonil & 2.24 & $0^{* *}$ & $12^{* *}$ & $2787^{\text {*k* }}$ & 1 & 0 & 2422 \\
\hline Mancozeb & 1.12 & $12^{* *}$ & $16^{* *}$ & $2684^{* *}$ & 4 & 0 & 2166 \\
\hline Mancozeb & 2.24 & $0^{* *}$ & $4^{* *}$ & $2881^{* * *}$ & $0^{* *}$ & 0 & 2197 \\
\hline Check & & 36 & 92 & 1980 & 16 & 0 & 2137 \\
\hline
\end{tabular}

${ }^{1}$ Significantly different over the check at $\mathrm{P}=0.01$.

${ }^{2}$ Significantly different over the check at $\mathrm{P}=0.05$. 
TABLE 4.-Disease index and yield of bean cv. Bonito and Naranjito at Lajas treated with fungicides to control leaf rust, February 1976

\begin{tabular}{|c|c|c|c|c|c|c|c|}
\hline \multirow{4}{*}{ Treatment } & \multirow{4}{*}{ Rate } & \multicolumn{6}{|c|}{ Cultivar } \\
\hline & & \multicolumn{3}{|c|}{ Blanca del Pais } & \multicolumn{3}{|c|}{ Naraniito } \\
\hline & & \multicolumn{2}{|c|}{ Disease index } & \multirow[b]{2}{*}{ Yield } & \multicolumn{2}{|c|}{ Disease incex } & \multirow[b]{2}{*}{ Yield } \\
\hline & & $\begin{array}{c}\begin{array}{c}\text { Pustule } \\
\text { intensity }\end{array} \\
\text { ins }\end{array}$ & $\begin{array}{l}\text { Degree of } \\
\text { defoliation }\end{array}$ & & $\begin{array}{l}\text { Pustule } \\
\text { intensity }\end{array}$ & $\begin{array}{c}\text { Degree of } \\
\text { defoliation }\end{array}$ & \\
\hline & $\mathrm{kg} / \mathrm{ha}$ & & & $\mathrm{kg} / \mathrm{ha}$ & & & $\mathrm{kg} / \mathrm{ha}$ \\
\hline Oxycarboxin & 1.12 & $48^{* * 1}$ & $60^{* * *}$ & $2100^{* 2}$ & 28 & 28 & 1843 \\
\hline Oxycarboxin & 2.24 & $48^{* *}$ & $44^{* * *}$ & 2007 & $4^{*}$ & $20^{* *}$ & 2030 \\
\hline Triforine & 0.60 & 64 & $72^{* *}$ & 1703 & $20^{*}$ & $20^{*}$ & 1890 \\
\hline Triforine & 1.12 & $40^{* *}$ & $44^{* *}$ & 2053 & $8 * *$ & $16^{* *}$ & 2310 \\
\hline Chlorothalonil & 1.12 & $44^{* *}$ & $60^{* *}$ & $2240^{* *}$ & $16^{*}$ & $20^{*}$ & 1913 \\
\hline Chlorothalonil & 2.24 & $32^{* * *}$ & $40^{* *}$ & $2193^{*}$ & $4^{* * *}$ & $8^{* *}$ & $2473^{*}$ \\
\hline Mancozeb & 1.12 & $44^{* *}$ & $44^{* *}$ & $2263^{* *}$ & $0^{* *}$ & $4^{* *}$ & 2287 \\
\hline Mancozeb & 2.24 & $16^{* * *}$ & $16^{* *}$ & $2333^{* *}$ & $0^{* *}$ & $0^{* * *}$ & $2543^{*}$ \\
\hline Check & & 76 & 96 & 1470 & 40 & 36 & 2077 \\
\hline
\end{tabular}

${ }^{1}$ Significantly different over the check at $P=0.01$.

${ }^{2}$ Significantly different over the check at $\mathrm{P}=0.05$. 
Rust levels were often too low in Isabela to show differences between systemic and contact fungicides. In those cases where differences existed, the contact fungicides as a group afforded better control than the systemics (table 5). In Lajas, contact fungicides as a group consistently reduced pustule intensity and degree of defoliation to a greater degree than did systemic fungicides as a group (table 5 ). Differences between systemics vs. contacts were greatest on the susceptible cv. Blanca del Pais. However, the advantage of contact fungicide use was also seen in the resistant cv. Naranjito, although to a lesser degree.

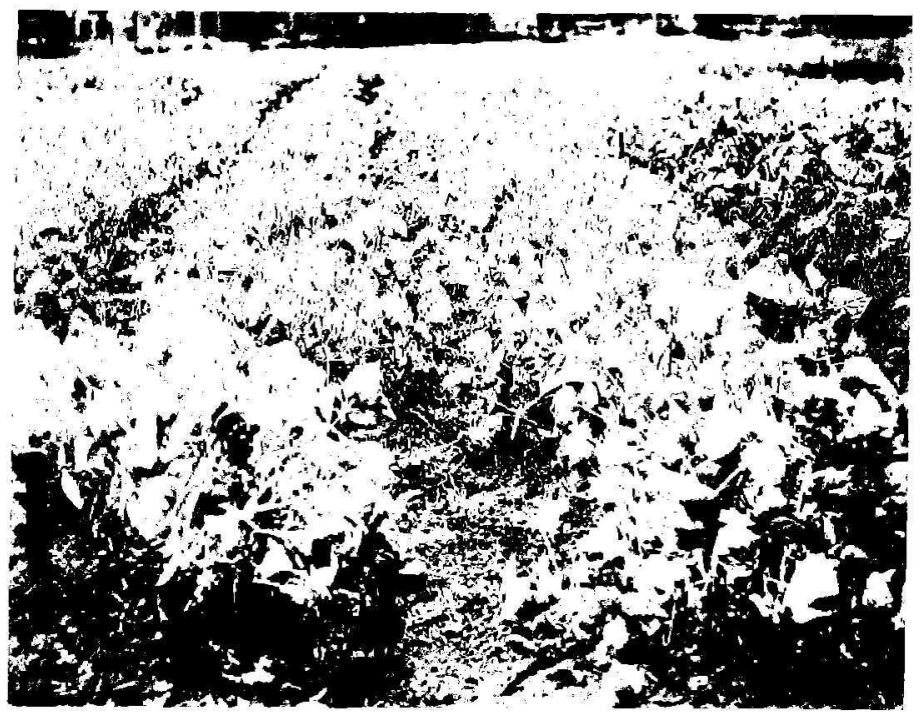

Fic. 3. - Good control of rust disease on cv. Blanca del Pais treated with weekly applications of mancozeb at the rate of $2.24 \mathrm{~kg} / \mathrm{ha}$.

Yields in 1976 were better in Isabela than in Lajas, in part because of lack of high levels of rust in Isabela. At both locations, use of contact fungicides improved yields when compared to systemics except on cv. Naranjito at Isabela (table 5).

This study's conclusion that contact fungicides chlorothalonil, and especially mancozeb, effectively protected bean foliage against this disease agrees with other reports. Simbwa-Bunnya (6) and So (7) reported that mancozeb was the most effective fungicide in controlling rust disease. Hilty (3) obtained satisfactory control with weekly applications of chlo- 
TABLE 5.-Comparison of systemic us. contact fungicides in two bean cultivars at two locations, February, 1976

\begin{tabular}{|c|c|c|c|c|c|c|c|c|}
\hline \multirow{2}{*}{ Item } & \multirow{2}{*}{ Location } & \multicolumn{3}{|c|}{ Blanca del Pais (susceptible) } & \multicolumn{3}{|c|}{ Naranjito (resistant) } & \multirow{2}{*}{ S.E. ${ }^{3}$} \\
\hline & & Systemic ${ }^{1}$ & Contact $^{2}$ & $\overline{\text { Check }}$ & Systemic & Contact ${ }^{2}$ & Check & \\
\hline \multirow[t]{2}{*}{ Pustule intensity } & Isabela & 6 & 4 & 36 & 2 & 2 & 16 & 2.9 \\
\hline & Lajas & 50 & 34 & 76 & 15 & 5 & 40 & 3.2 \\
\hline \multirow{2}{*}{ Degree of defoliation } & Isabela & 38 & 15 & 92 & 0 & 0 & 0 & 3.5 \\
\hline & Lajas & 55 & 40 & 96 & 21 & 8 & 36 & 3.0 \\
\hline \multirow[t]{2}{*}{ Yield $(\mathrm{kg} / \mathrm{ha})$} & Isabela & 2407 & 2788 & 2980 & 2127 & 2282 & 2137 & 83.3 \\
\hline & Lajas & 1966 & 2257 & 1470 & 2018 & 2304 & 2077 & 111.1 \\
\hline
\end{tabular}

${ }^{1}$ Mean of systemic fungicides oxycarboxin and triforine over all rates.

${ }^{2}$ Mean of contact fungicides chlorothalonil and mancozeb over all rates.

${ }^{3}$ Standard error of the difference between systemic and contact fungicide means. Differences greater than twice the standard error are considered significant. 


\section{JOURNAL OF AGRICULTURE OF UNIVERSITY OF PUERTO RICO}

rothalonil (Bravo 75w) at the rate of $3.36 \mathrm{~kg} / \mathrm{ha}$. There is a marked tendency for plant pathogens to develop resistance against chemicals, especially if these chemicals are systemic fungicides which fail to provide good protection against a specific disease. This could be the case with the bean rust fungus, a pathogen which can easily mutate, producing races possibly resistant to systemic fungicides.

Contrary to the results of this study, some researchers have found that systemics such as oxycarboxin and triforine provide the best control of bean rust and improve seed quality $(1,2,4)$. The best control method might be the use of contact fungicides in combination with systemics to minimize the chances of fungicide induced mutations, or selection of fungicide resistant races to this pathogen. This practice has already been used successfully in the control of bean rust. Yoshii and Granada (8) found that three applications of chlorothalonil and two of oxycarboxin, or one of oxycarboxin and two of mancozeb, were effective to control rust.

\section{RESUMEN}

Los fungicidas de contacto y los sistémicos combatieron la roya, Uromyces appendiculatus, en dos cultivares de habichuela en dos localidades (Lajas e Isabela) de Puerto Rico. La eficacia de los fungicidas varió con la concentración, la localización, la cultivar y la incidencia de la roya. En las cultivares sembradas en Lajas, los fungicidas de contacto chlorothalonil y mancozeb fueron más eficaces que los sistémicos oxycarboxin y triforine en controlar la enfermedad y en aumentar la producción. En Isabela, donde la incidencia de roya fue más baja y la diferencia entre fungicidas no fue muy marcada, los fungicidas de contacto fueron los más eficaces. Mancozeb fue el fungicida más eficaz para combatir la roya y para aumentar la producción. Los resultados sugieren que algunos fungicidas en combinación con cultivares resistentes a la enfermedad pueden aumentar la producción de la habichuela.

\section{LITERATURE CITED}

1. Almeida, A. M. R., G. M. Chavesi, L. Zambolin y L. M. Oliveira, 1977. Effectos terapeúticos y preventivos de productos sistémicos en plantas de frijol atacadas por la roya bajo condiciones de invernadero. Fitopatología Brasileira. 2: 43.

2. Dongo, D. S., 1971. Control químico de la roya (Uromyces phaseolitypica) en frijol. Invest. Agron. 2 (1): 23.

3. Hilty, J. W. and C. A. Mullins, 1975. Chemical control of snaphean rust. Tenn. Farm Home Sci. 93: 4.

4. Okioga, D. M. and A. A. Jaffer, 1972. Studies on the efficacy of various systemic lungicides against bean rust-Uromyces appendiculatus (Pers.) Lev.-Misc. Rep. Trop. Pestic. Res. Inst., Arusha, Tanzania. No. 805. (Abstract \#2783). Rev. Plant Pathol, Vol. 52. 
5. Sherwood, R. T. and D. J. Hagedorn, 1958. Determining the common root rot potential of pea fields, Agric. Exp. Stn. Univ. Wis. Bull. 531.

6. Simbwa-Bunnya, M., 1972. Fungicidal control of bean diseases at Kawanda, Uganda, Plant Dis. Rep. 56 (10): 901.

7. So, V, 1971. Control of bean rust-Urumyces appendiculatus (Pers.) Unger-in Hong Kong, Agric. Sci. Hong Kong. 1 (516): 265. (Abstract \#3678) Rev. Plant Pathol. Vol. 53.

8. Yoshii, K. and G. A. Granada, 1976. Control químico de la roya del frijol en el Valle del Cauca, Fitopatologia 11 (2): 66. 